COVID-19 and the
Ongoing Problem of
Educational Efficiency

\section{Brock Brock Education}

A journal of educational research and practice

2020 Vol. 29 (2) 18-23

https://journals.library.brocku.ca/brocked

\title{
Michael Mindzak*
}

Brock University

\begin{abstract}
In many ways, the current COVID-19 crisis has provided the impetus, or else opportunity, to examine the state of education and schools today. Currently, responses have focused largely on instrumental, pragmatic concerns that would allow formal education to "return to normal" as soon as possible. Perspectives such as these demonstrate the ongoing prevalence of values surrounding educational efficiency and how the pursuit of efficiency continues to dominate the field of educational reform. Thus, this essay reflects on the ideas of place, pace, and purpose in education surrounding the problematic nature of efficiency and asks instead to consider how we might shift our gaze to reconceptualize education in the contemporary period and beyond. Keywords: educational reform, efficiency, commodification, standardization

*mmindzak@brocku.ca
\end{abstract}




\section{The COVID-19 Crisis}

Looking within the educational community, reactions to the COVID-19 situation in many contexts have appeared to be principally focused on pragmatic concerns such as the operation of schools and the need for learning continuity (Greene, 2020; McMurtrie, 2020). Such reactions can be understood as mainly instrumentalist anxieties surrounding the provision and delivery of education in order to return to "normalcy" as quickly as possible (Kayyem, 2020). Thus, the concern raised here is that perhaps we are asking the wrong question; that is, rather than asking how can we return back to doing what we were doing before, we might ask instead how we might do things differently. However, the prevailing concern for the former over the latter is apparent in the prevalence of efficiency as an educational raison d'être (Lockheed \& Hanushek, 1994). From this perspective, this essay reflects on the ideas of place, pace, and purpose in education and seeks to critically examine the relevance, if not importance, of such ideas across the vast endeavour that is formal education. The current pandemic situation we find ourselves in can provide educators with an opportunity to reconsider how we understand-or else are made to understand-the concept of educational efficiency and how this pervasive value system continues to dominate much of our thinking about schools, students, and education itself.

\section{Educational Efficiency}

The pursuit of efficiency lies at the very heart of universal schooling. Since being brought forward by Callahan (1962), the notion of critically examining the idea of efficiency within the sphere of education has been theorized further (Gross Stein, 2002). This cult of efficiency reveals itself as a logic deeply embedded in the norms, values, and beliefs that guide the provision of education. Indeed, all those involved in education or its administration quickly realize the hegemony of limited resources (Boyd, 2004). Thus, efficiency is about managing and allocating finite resources, finding ways to do more with less, and doing things faster (Welch, 1998). In contrast to efficacy, efficiency in and of itself focuses solely on the maximization of limited resources without concern for other values. While invoking efficiency may then be advantageous towards attaining certain ends (Heath, 2001), approaching education, and in particular public schooling, from this perspective poses numerous dangers (Gross Stein, 2002). Indeed, as Menashy (2007) notes, many educational reforms are often rooted in misleading understandings of efficiency. Today, we may begin to ask how COVID-19 currently occupies our thinking about both efficiency and education.

\section{Education and Place}

Moving towards forms of teaching and learning that do not reside in a fixed physical location or place continues to make educators revaluate the traditional classroom with one that is not necessarily limited by considerations of space. Most prominently, educational technology has sought to fill the space left by schools as they have (now increasingly) transitioned to digital 
modalities. Thus, as educators grapple with developing new pedagogical practices and strategies alongside training with new tools and applications, the place of education increasingly moves beyond the schoolhouse or classroom. In light of current events, the evaluation of places is extremely relevant as the logic of efficiency pushes towards more private rather than public spaces (Gross Stein, 2002). Thus, promoted by COVID-19, an enhanced role by educational technology may represent an increasing shift towards further privatization, commodification, or else the automation of education (Mindzak, 2020) whereby technologists rather than pedagogical professionals increasingly shape the content and delivery of education (Bushweller, 2020). Schools as structures serve communities in many ways, and indeed schools remain important public spaces in an era when such spaces are increasingly becoming privatized (Harvey, 2006). Hence, the primary concern raised here is how an emphasis on efficiency pushes educational technology forward and what the logic beyond such tools might represent (Klein, 2020) to schools, students, and public places. ${ }^{1}$

\section{Education and Pace}

The current pandemic situation has asked individuals, groups, and organizations to respond rapidly to solve problems as they have emerged. In education, this has been witnessed at all levels, where educators, administrators, and parents have all sought to respond with immediacy to ensure schooling continuity. Thinking about time or pace in this way, the value system of efficiency is revealed throughout the structure of formal education systems. The very thought of an extended period without any formal education is not only viewed as unreasonable but also encountered with fear. Time is a resource that, today perhaps more so than ever, appears limited by current arrangements and discourses of human capital, productivity, and efficiency. We might recall that education can be conceptualized as not only the accumulation of relevant experiences (Dewey, 1938) but even towards an actual lack of formal schooling (Illich, 1971), or even as leisure (Gary, 2017; Ildefonso-Sanchez, 2019; Russell, 1932). Indeed, this may be the first time in recent memory that schools, students, and educators have been pushed towards more leisure time rather than labour time. The rush to return to the latter indicates our profound belief in the norms surrounding efficiency in how we think about and conduct education. Time structures can act as measures of discipline (Thompson, 1967) and educational efficiency asks us to return, quickly, to our previous habits and practices, rather than towards perhaps developing new ones. As Berg and Seeber (2016) highlight, conceiving education in a slower manner opens up numerous possibilities towards both rethinking and reshaping what education is as well as what it can be.

\footnotetext{
1 There are numerous additional concerns in this regard, particularly with respect to the evolving role of
} educational technologies in terms of privacy, profit, and exploitation (see Zuboff, 2019). 


\section{Education and Purpose}

Critically interrogating the notion of efficiency also forces us to ask hard questions concerning the purpose of education and its broader role in our world. Educational efficiency views schooling as little more than job preparation (Callahan, 1962) in order to meet the everevolving demands of capital (Bowles \& Gintis, 1976). Education is reduced to an individualized product or commodity (Giroux, 1985) found within a marketplace offering more choices and with an emphasis on private rather than public consumption (Gross Stein, 2002). Briefly, all that will be noted here is that an efficient education system understands schooling and learning in largely capitalistic terms - without regard for the plethora of other ways to think about both how and why we educate. Whether focused on democratic ideals (Dewey, 1916) or human liberty and emancipation (Freire, 1970/2000), the process of education is not predestined and does not need to be directly related to strictly meeting the needs of the market. While schools do not exist in a vacuum from broader sociocultural, socioeconomic, and sociopolitical dynamics (Manzer, 1994), including crises such as COVID-19, the purpose(s) of education remain vast. The logic of educational efficiency thus seeks to limit or standardize our gaze in one direction about what education can be rather than allowing for the opportunity to look in wider directions and explore new horizons.

\section{Conclusion}

Efficiency is not an inherently bad thing-resources are always limited, and we are always challenged with how to allocate such resources fairly and equitably. Crises such as COVID-19 provide opportunities to reassess and confront issues such as access and opportunity as well as to develop new pedagogical practices as schools have closed their doors (Bennett, 2020). However, the rush to return to normal may be best understood as a challenge of efficiencyreflecting its values and touching on the very foundation of what education means and how it is to be conducted. Instead of attempting to quickly move back into previous habits, norms, and practices could we instead actually begin to conceptualize what inefficient education might look like? As Callahan (1962) understood crucially in his own time, we remain concerned more with thinking about how we can best $d o$ education rather than asking about what education might be best. As he also noted, there is no cheap, easy, or efficient way to accomplish thisespecially if we are to assert the importance of education for holistic individual development and social democratic ideals.

The question I would like to leave the reader with is this: just because education can be done efficiently, does that mean it should be done this way? If we continue to find ways to fashion education through the values of efficiency-faster, cheaper, and less (human) resourceintensive-are we truly making education better, more significant, or more sustainable for our students? Current events have, it seems, for the first time in a long time, provided the 
opportunity to step back and ask important questions such as where and how we allocate resources, time, and for what purposes. As we navigate the complexities of COVID-19 and education in 2020 and beyond, educators must continue to ask serious questions about educational efficiency and the implications of such thinking for current and future students.

\section{References}

Bennett, P. W. (2020, May 11). This grand distance-learning experiment's lessons go well beyond what the students are learning. CBC. https://www.cbc.ca/news/opinion/opiniondistance-learning-education-covid-1.5547062

Berg, M., \& Seeber, B. K. (2016). The slow professor: Challenging the culture of speed in the academy. University of Toronto Press.

Bowles, S., \& Gintis, H. (1976). Schooling in capitalist America: Educational reform and the contradictions of economic life. Basic Books.

Boyd, W. L. (2004). Are education and efficiency antithetical? Journal of Educational Administration, 42(2), 160-173. https://doi.org/10.1108/09578230410525586

Bushweller, K. (2020, June 2). How COVID-19 is shaping tech use. What that means when schools reopen. Education Week.

https:/ / www.edweek.org/ew/articles/2020/06/03/howcovid-19-is-shaping-tech-usewhat.html

Callahan, R. E. (1962). Education and the cult of efficiency: A study of the social forces that have shaped the administration of the public schools. University of Chicago Press.

Gary, K. (2017). Neoliberal education for work versus liberal education for leisure. Studies in Philosophy and Education, 36, 83-94. https://doi.org/10.1007/s 11217-016-9545-0

Dewey, J. (1916). Democracy and education: An introduction to the philosophy of education. Macmillan.

Dewey, J. (1938). Experience and education. Macmillan.

Freire, P. (2000). Pedagogy of the oppressed. Bloomsbury. (Original work published 1970)

Giroux, H. (1985). Critical pedagogy, cultural politics and the discourse of experience. Journal of Education, 167(2), 22-41. https://doi.org/10.1177\%2F002205748516700204

Greene, P. (2020, July 9). Want schools open in the fall? All the money in the world can't solve these problems. Forbes. https://tinyurl.com/y6bdf5ff

Gross Stein, J. (2002). The cult of efficiency. House of Anansi Press.

Harvey, D. (2006). The political economy of public space. In S. Low \& N. Smith (Eds.), The politics of public space (pp. 17-33). Routledge. 
Heath, J. (2001). The efficient society: Why Canada is as close to utopia as it gets. Penguin Canada.

Ildefonso-Sanchez, G. M. (2019). Revaluing leisure in philosophy and education. Studies in Philosophy and Education, 38, 163-176. https://doi.org/10.1007/s11217-019-09651-6

Illich, I. (1971). Deschooling society. Harper \& Row.

Kayyem, J. (2020, July 6). Reopening schools was just an afterthought. The At/antic. https:/ / www.theatlantic.com/ideas/archive/2020/07/reopening-bars-easy-schools-aredifficult $/ 613861$ /?utm_source= pocket-newtab

Klein, N. (2020, May 13). How big tech plans to profit from the pandemic. The Guardian. https:/ /www.theguardian.com/news/2020/may/13/naomi-klein-how-big-tech-plansto-profit-from-coronavirus-pandemic?CMP=Share_iOSApp_Other

Lockheed, M. E., \& Hanushek, E. (1994, March). Concepts of educational efficiency and effectiveness (Human Resources Development and Operations Policy Working Papers). http:/ / documents 1.worldbank.org/curated/en/727651468739517517/pdf/multipage.pdf

Manzer, R. (1994). Public schools and political ideas: Canadian educational policy in historical perspective. University of Toronto Press.

McMurtrie, B. (2020, May 5). Are colleges ready for a different kind of teaching this Fall? The Chronicle of Higher Education. https://www.chronicle.com/article/Are-Colleges-Readyfor-a/248710?cid=wsinglestory_hp_la

Menashy, F. (2007). The end of efficiency: Implications for democratic education. The Journal of Educational Thought/ Revue de la Pensée Éducative, 47(2), 165-177. https://doi.org/10.11575/jet.v41i2.52515

Mindzak, M. (2020, February 17). What happens when a machine can write as well as an academic? University Affairs. https://www.universityaffairs.ca/opinion/in-myopinion/what-happens-when-a-machine-can-write-as-well-as-an-academic/

Russell, B. (1932, October). In praise of idleness. Harpers. https://harpers.org/archive/1932/10/in-praise-of-idleness/

Thompson E. P. (1967). Time, work-discipline, and industrial capitalism. Past \& Present, 38(1), 56-97. https://doi.org/10.1093/past/38.1.56

Welch, A. (1998). The cult of efficiency in education: Comparative reactions on the reality and the rhetoric. Comparative Education, 34(2), 157-175. https://doi.org/10.1080/03050069828252

Zuboff, S. (2019). The age of surveillance capitalism: The fight for a human future at the new frontier of power. PublicAffairs. 